\title{
Are Shareholders Adequately Represented in the Corporate Governance Process?
}

\section{Abbott Haron*}

MBA, Higher Colleges of Technology, Sharjah, UAE

"Corresponding author: Dr. Abbott Haron, MBA, Higher Colleges of Technology, Sharjah, UAE, Tel: +374 10 23-72-61; E-mail: abbottjharon@hotmail.com

Received date: December 05, 2014, Accepted date: January 19, 2015, Published date: January 27, 2015

Copyright: (c) 2015 Haron A. This is an open-access article distributed under the terms of the Creative Commons Attribution License, which permits unrestricted use, distribution, and reproduction in any medium, provided the original author and source are credited.

\section{Introduction}

In this assignment the author, attempts to express the opinion that the shareholders are adequately represented in the corporate governance process by using the banking industry among others to enforce that hypothesis. Because of the absence of moral purpose in the banking industry [1], Lord Myners, Gordon Brown's City minister, has turned to the more actual matter of how best to inspire more active shareholders oversight of businesses [2]. Lord Myners's proposed that long-term shareholders should be allowed greater voting rights than short-term speculators; this proposal has been criticized as foolish and unfeasible by his colleagues, short-term investors and the banking sector. Consequently, it should not be a shock to see the rights of shareholders trampled on, when creative, ethical and sensible ideas are shot down by the people who should be looking after the interest of their investors and citizens [3].

The financial crisis of 2008 has revealed that markets can seem to favor speculation over long-term ownership, hence the many recent investigations into reducing speculation in the oil markets [2]. They have also exposed that equity sometimes is not as solid as it might appear - hence the banking crisis. Carney, Gedajlovic and Sur [4] argued that restoring confidence in the system will require shareholders who take more than just a passing interest in the longterm health of the businesses they own, this demonstrates that some sections of shareholders are also to blame for the financial and economic problems [5]. An example of this is Porsche, who has a complex system of preference and ordinary shares; suggest that splitlevel systems are no answer. Indeed, Europe's experience suggests that having two levels of shareholders leaves second-tier investors captive to first-tier interests [2].

According to Shleifer and Vishny [2] the last ten years have seen a substantial amount of evidence, which acknowledged the prevalence of managerial behavior that does not serve the interests of shareholders. Most of this evidence originated from the capital market in the form of "event" studies. The idea is that if the stock price drops when executives announce a particular action, then this action must serve the interests of executives rather than those of the shareholders. While in some situations this extrapolation is not justified because the managerial action, while serving the interests of shareholders, unintentionally conveys to the market some unrelated bad news about the firm [2].

One contributing factor to the complexity of the relationship between managers and shareholders is that the contracts that the managers and shareholders sign cannot require too much interpretation if they are to be enforced by external courts [6]. For example, in the United States, the role of courts is broader than anywhere else in the world. Nevertheless even there, the alleged business judgment rule keeps the courts out of the affairs of businesses [6]. In most of the rest of the world, courts only get involved in enormous violations by executives of shareholders' right. An additional factor are the cases where financing requires gathering of funds from many shareholders, these shareholders themselves are often small and too poorly informed to exercise even the control rights that they essentially have [7]. The free-rider issue faced by individual shareholders makes it unexciting for them to learn about the companies they have backed, or even to take part in the governance [8].

\section{Does Corporate Governance Differ Greatly From One Country To Another?}

The short answer to this question is yes, however we need to understand the reasons for this inconsistency. In the shadows of the far-reaching financial collapses of viable companies such as Enron, WorldCom, and Parmalat, the corporate world has awoken to the necessity for implementation of sound corporate governance practices in the 21 st century [9]. In view of these corporate scandals in the international economy, substantial recommendations in the governance of companies have been given. These recommendations include the Treadway Commission, the Sarbanes-Oxley Committee, the Cadbury Committee, the Greenbury Committee, the Higgs Committee, and the King Committee of 2002. Such recommendations have led to the improvement of various corporate governance acts and codes in different countries and across the global market place [10]. Using the Zimbabwean scenario, post-independence Monetary Authorities in Zimbabwe had limited intrusion with banking operations; Banks appeared to have kept back demands for corrupt dealings despite prevalent corruption in other economic sectors. The banking law was enacted at a time when all the banks were foreignowned [11], sensible regulation of banks appeared to be unnecessary. The Banking Act of Zimbabwe, was the only operational law, and it took no notice of requirements on insider lending, not anything on the maximum proportion of shareholder funds that could be lent to a particular borrower, no definition of risk assets, nor the quantity of capital essential to support bank lending, and no provision for scrutiny of banks except where a case was made for an investigation into dishonest activities [11].

The corporate governance structures of multinational banks in most countries were made stronger in the late 1970s due to regulatory controls of some countries, who were not meeting home country standards [11]. These regulations encompassed the solvency and liquidity requirements. Tightening of corporate governance approaches was required because the domestic banks could easily approach central banks as the lender of last resort not like multinational banks. The justification of tightening corporate governance structures was for the defense of depositors' funds; need to have control over the volume of money and credit and the restricting of every tendency of mono poly power in the banking industry [11]. Furthermore, this reflects another 
Citation: Haron A (2015) Are Shareholders Adequately Represented in the Corporate Governance Process?. Bus Eco J 6: 132. doi:

Page 2 of 2

reason for the inconsistency of global and local corporate governance application.

Monks and Minow [10] argued that multinationals selected from a range of corporate governance strategies, this included international, worldwide, and multinational standards. They however stressed that; the most usually practiced corporate governance strategy was the multinational strategy, which gave emphasis to adoption of policies based on variations in the operating environments. This would allow them to adjust to and in many places take advantage of the local inconsistencies to their advantage, regardless whether it was what they believed in or practiced in their home country. Multinationals adjusted their services and management practices according to each country. This gave management independence, which were typically nationals of the hosting country and thus familiar with that country's corporate governance requirements [10].

The research done in this field has concluded that domestic organisations had lower standards of corporate governance than multinational organisations in terms of size and election of the board of directors, transparency of managers' compensation, principal agency problem, and dissemination of the code of ethics [12]. In addition, the relatively better share prices by multinational organisations over domestic organisations implied that multinational organisations had more effective corporate governance strategies than domestic organisations [13-23].

\section{References}

1. Demidenko E, McNutt P (2010) The ethics of enterprise risk management as a key component of corporate governance. Int J of Social Econ 37: 802-815.

2. Shleifer A, Vishny RW (1997) A Survey of Corporate Governance. The J of Financ 52: 737-783.

3. Anca P (2012) Corporate Governance: Principles and Regulations. J o f Electrical and Electronics Engineering 5: 155.

4. Carney M, Gedajlovic E, Sur S (2010) Corporate governance and stakeholder conflict. J Manage Gov 15: 483-507.

5. Döscher T, Friedl G (2011) Corporate governance, stakeholder power, and executive compensation. OR Spectrum 33: 309-331.

6. Beck A (1989) Company Law: Minority Shareholders And Allotments For An I. Aus Bus Law Rev 17: 321.
7. Ananymous (2014) NCC Moves to Enhance Stakeholders' Role With Corporate Governance Code.

8. Wright M, Filatotchev I, Buck T, Bishop K (2003) Is Stakeholder Corporate Governance Appropriate in Russia? J of Manage and Gov 7: 263-290.

9. Dam L, Scholtens B, Sterken E (2007) Corporate Governance and International Location Decisions of Multinational Enterprises. Journal compilation 15.

10. Monks RA, Minow N (2011) Corporate Governance. John Wiley \& Sons.

11. Ndlovu MW, Bhiri T, Mutambanadzo T, Hlahla BP (2013) A Comparative Analysis of the Corporate Governance Practices in Multinational and Domestic Banks in Zimbabwe. J of Emerging Trends in Econ and Manage Sci 4: 473-480.

12. Jesover F (2001) Corporate Governance in the Russian Federation: the relevance of the OECD Principles on shareholder rights and equitable treatment. Practice-Based Papers 9: 79.

13. Cosneanu S, Russu C, Chiritescu V, Badea L (2013) Foundations and Principles of Corporate Governance. Valahian J of Econ Stud 4: 31-38.

14. Filatotchev I, Wright M (2011) Agency Perspectives on Corporate Governance of Multinational Enterprisesjoms. J of Manage Stud 48: 472-486.

15. Hilb M (2005) New Corporate Governance: from good guidelines to great practice. New Corporate Governance 13: 269-581.

16. Irvine W (1988) Corporate Democracy and the Rights of Shareholders. J of Bus Ethics 7: 99.

17. Jo H., Harjoto MA (2011) Corporate Governance and Firm Value: The Impact of Corporate Social Responsibility. J of Bus Ethics 103: 351-383.

18. Kulkani R, Maniam B (2014) Corporate Governance - Indian Perspective. Int J of Trade, Econ and Financ 5: 364-368.

19. Mallin C, Melis A (2012) Shareholder rights, shareholder voting, and corporate performance. J Manage Gov 16: 171-176.

20. Pande S, Ahmad VA (2014) A Theoretical Framework for Corporate Governance. Ind J of Corporate Gov 7: 56-72.

21. Tuan LT (2012) Corporate social responsibility, ethics, and corporate governance. Social Responsibility J 8: 547-560.

22. Wanyama S, Burton B, Helli C (2009) Frameworks Underpinning Corporate Governance: Evidence on Ugandan Perceptions. Corporate Governance: An Int Rev 17: 159-175.

23. Windsor D (2009) Tightening corporate governance. J of Int Manage 15: 306-316. 